\title{
BRATSLAV HASIDS: HISTORICAL ASPECTS OF THE ORIGIN AND FUNCTIONING OF THE ORTHODOX MOVEMENT IN JUDAISM
}

\author{
Lyudmyla Radchenko ${ }^{l}$ \\ ${ }^{1}$ Department of Tourism and Social Humanities Sciences, Kharkiv College of Trade and Economics, Kyiv National University of Trade \\ and Economics, Kharkiv, Ukraine, \\ kharkiv@htek.com.ua \\ ORCID: http://orcid.org/0000-0002-2514-7549
}

ARTICLE INFO

Article history:

Received date 02.02.2021

Accepted date 16.03.2021

Published date 30.04 .2021

Section:

History

D O I

$10.21303 / 2313-8416.2021 .001788$

KEY W ORDS

Hasidism

Bratslav Hasids

the Orthodox movement

Judaism

Rabbi Nachman

Tzaddik and Tzaddikism

Rosh Hashanah

\section{A B S TRACT}

The object of research: Bratslav Hasids as a component of the orthodox movement in Judaism.

Investigated problem: historical aspects of the emergence of the orthodox movement in Judaism, the reasons for its spread among the Jewish population of Volhynia, Galicia and Podillya.

The main scientific results: the historical aspects of the origin of the orthodox movement in Judaism, the reasons for its spread among the Jewish population of Volhynia, Galicia and Podillya, as a way to achieve the formation of the Jewish religion are analyzed. The role of one of the most influential movements of Bratslav Hasids, founded and led by Rabbi Nachman of Bratslav, the main guidelines of his teachings, the reasons for its rapid spread among the communities of Ukraine and many countries, the place of tzaddiks (righteous) heirs-mediators between God and believers. Highlights the thorny path that believers took to obtain permission to celebrate the Jewish New Year - Rosh Hashanah, other holidays at the grave of his teacher and mentor, to resolve issues regarding the coordination and construction of the synagogue of the Pantheon-Temple of Rabbi Nachman, hotel, mikvah (ritual pool) for recitation before prayer), other objects. A prominent place in the study is identified by the problems of pilgrims arriving in Uman, their resettlement, everyday life, relations with the local population, law enforcement agencies, security issues and more. Given the growing interest in the teachings of Tzaddik Nachman, the phenomenon of this phenomenon needs further study.

The area of practical use of the research results: the results of the study can be used by public administration and local government in determining public policy in the field of religion, mechanisms for solving its current problems, during the development and teaching of courses on public administration, history of religion, world history and history of Ukraine. Innovative technological product: on the basis of numerous sources, materials, some of which are introduced into scientific circulation for the first time, a significant gap is filled in ideas about the process of religious orthodox movement in Judaism, the reasons for its spread in Ukraine and many countries and the problem of pilgrims coming to Uman, which contributed to the transformation of the city of Uman into the world capital of Bratslav Hasids. Scope of the innovative technological product: the practice of forming, implementing and improving the system of state regulation by religious organizations.

(C) The Author(s) 2021. This is an open access article under the Creative Commons CC BY license

\section{Introduction}

\section{1. The object of research}

Bratslav Hasids - one of the most influential orthodox movements in Judaism, widespread among the Jewish population of Volhynia, Galicia and Podillya; the main goal of which is to achieve the independence of the Jewish religion.

The founder of Hasidism in Ukraine was a rabbi and healer Israel Baal Shem Tov (nicknamed Besht) from Medzhibozh.

Without rejecting traditional doctrine, the Hasidim emphasize the need for an emotional attitude towards religion and spiritual renewal. According to the doctrine, pious Jews should be 
distinguished not by strict observance of the law and not by asceticism, but by a cheerful heart of reverence and humility.

Hasidism preaches the principle that the tzaddik is the mediator between God and the believer.

\section{2. Problem description}

The paper substantiates the principles of understanding the limits of managerial influence of the state in the field of religion. Having established that the limits of state influence are determined by the norms of the current legislation, the structural components of the sphere of religion were analyzed for the sufficiency of such influence.

Studies of the historical aspects of the origin and functioning of the orthodox movement in Judaism show that Hasidism is a movement in Judaism, widespread among the Jewish population of Volhynia, Galicia and Podillya, which aims to achieve the independence of the Jewish religion. A number of works are devoted to the theoretical basis of substantiation of historical aspects of the origin of the Hasidism movement [1-3] and in particular to the teachings of Bratslav Hasids [4-6], the life and teachings of Rabbi Nachman [7-9].

Without rejecting traditional doctrine, the Hasidim emphasize the need for an emotional attitude towards religion and spiritual renewal. According to the doctrine, pious Jews should be distinguished not by strict observance of the law and not by asceticism, but by a cheerful heart of reverence and humility [4].

Among the Hasids, the tzaddik heirs, the religious leaders of certain Hasidic groups, who are credited with miraculous abilities, enjoy great authority. Hasidism preaches the principle that the tzaddik is the mediator between God and the believer [9].

Nowadays, there is a growing interest in the teachings of Tzaddik Nachman, one of the prominent ideologues of the Jewish nation, and about 30,000 pilgrims from more than 20 countries come to Uman every year, so the phenomenon of this phenomenon deserves further study.

Researchers of early Hasidism believe that it was the institution of Tzaddikism that gave Hasidism that unique, inimitable face that radically distinguishes it from Jewish currents [5, 7].

Hasidism owes much of its extraordinary success to the fact that its founder, Baal Shev Tov, was able to give his teaching a practical character, the metaphysical foundations of which were pantheism (a philosophical doctrine that identifies God with nature) and the recognition of human-God interactions and also an optimistic attitude to life and people $[6,8]$.

\subsection{Suggested solution to the problem}

It is necessary to supplement the legislation of Ukraine and its state policy in the field of religion, to subordinate its goals to rapprochement with the modern system of European law and relevant practice in matters of the need to separate spiritual and secular power, guarantee all religious associations legal personality, prevent and combat discrimination on religious grounds, increasing religious tolerance in society.

The aim of research is to substantiate the emergence of the religious orthodox movement in Judaism of Bratslav Hasids, the reasons for its rapid spread in Ukraine and many countries and religious guidelines, conditions that contributed to the transformation of Uman into the world capital of Bratslav Hasids.

\section{Materials and Methods}

The methodological basis of the study is a system of scientific principles, approaches and methods of cognition, aimed at a comprehensive study of socio-political phenomena, facts, events, objective reproduction and analysis of historical realities. The work is based on the fundamental principles of scientific knowledge: historicism, system, comprehensiveness, alternativeness.

This revealed the historical process of origin and functioning of the religious orthodox movement in Judaism of the Bratslav Hasids, the reasons for its spread among the Jewish population of Volhynia, Galicia and Podillya, as a way to achieve the formation of the Jewish religion.

The research was carried out by analyzing and generalizing the historical process of origin and functioning of the religious orthodox movement in Judaism of the Bratslav Hasids on the basis of analytical and information sources. 


\section{Results}

Since the founding of Hasidism, the mystical movement has had a large number of different directions and branches. Some of them were named after the cities (localities) of their founders: Hasids "Vyzhvytsky", "Belsky", "Skvyrsky", "Bratslav" and others [9].

One of the most influential among them is the Bratslav Hasidic movement. Its founder and spiritual leader was the tzaddik (righteous) Rabbi Nachman of Bratslav.

From childhood Nachman showed extraordinary abilities, had a brilliant mind, was very erudite, pious, studied the Talmud.

At the age of 14, Rabbi Nachman married the daughter of a wealthy tenant of landed estates, Rabbi Ephroim of Husiatyn, inheriting 300 rubles. During this period of his life he accepted the title of tzaddik, formulated his ideas and began to preach them. The Jews chose him as their teacher when he was less than twenty years old, and began to call him Rabbi Nachman, that is, "Teacher Nachman". Since then, a circle of his disciples and followers has formed around the tzaddik.

Rabbi Nachman believed in God infinitely. He was one of the first rabbis to preach the idea that prayer should not be weeping, but should be accompanied by song and dance. There is a certain symbolism in this: the eternally oppressed people rejoice not only because they have managed to preserve their faith, but also because of their writing and culture. Rabbi Nachman advised Jews to pray in Yiddish, which was more understandable and accessible to them.

Among other areas of Hasidism in prayers and religious rites Bratslav always stood out with deep faith and immediacy.

Rabbi Nachman was not attracted to wealth and accumulation. He often repeated that the simpler and more sincere a person is, the closer he is to God. The closest to him is the poor man, the one who earns his living by his own labor, with his own hands, proclaiming Hasidic sermons in the Medvedivka synagogue [10].

Going to go to the Holy Land, he sold everything he had, and the Hasidim collected a small amount of money and after six months of exhausting travel, the rabbi came to Eretz Israel (Land of Israel). In the Holy Land he studied Kabbalah, visited the graves of great Jewish thinkers, and prayed at their graves. He experienced many adventures and even was taken prisoner by the Turks, where he was redeemed by the Jewish community of Rhodes.

Returning from the Holy Land, Rabbi Nachman first settled in Zlatopol, and later moved to Bratslav. It was here and in Nemyriv that most of his followers were. From 1802, Bratslav became the center of the Hasids of the Bratslav rabbi, where believers listened to sermons and teachings.

The modern Jewish researcher Abraham-Yitzhak Green emphasized that Rabbi Nachman's speeches combined the genius of the teacher and the excellent ancient Hebrew literary language of the student - a rare virtue among Hasidic authors. The works of Rabbi Nachman were published directly by his closest student, Rabbi Nathan of Nemyriv. Rabbi Nathan can be considered the first hagiographer of the founder of Bratslav Hasidism [11].

In 1802, Rabbi Nachman visited Uman and visited the Jewish cemetery, where 30,000 victims of the 1768 massacres were buried. Impressed by their courage to remain Jews, Nachman ordered that he be buried among the Uman martyrs after his death.

The last years of Nachman's life were very difficult: his two-year-old and younger son died, and a year later his wife, Tzaddik himself, also contracted tuberculosis.

During a fire in Bratslav in 1810, his house burned down, and he lost it and moved to Uman. When his health improved, he walked around Sofiyivka Park. The following terms were written here: "A flowing stream is a source of wisdom", "The whole world is a very narrow bridge, and the main thing is not to be afraid of anything" and others [10].

Before Rosh Hashanah (Jewish New Year), Tzaddik Nachman's health deteriorated and he delivered a sermon that was his last address to the faithful.

Rabbi Nachman died in October 1810 at the age of thirty-eight. He was buried in the long-suffering land of Uman so that he could save the souls of the dead.

The teachings of Rabbi Nachman of Bratslav, one of the five most prominent ideologues of the Jewish nation, contain the following guidelines:

- man must be constantly spiritually renewed, so the mission of the tzaddik is to correct souls;

- the main thing in life is to sow peace in the heart. The absence of this is the cause of wars and chaos; 
- faith is transmitted not by evidence, but by one's own example, stories, parables;

- there is no time in the universe: the past has passed, the future has not yet come, the present is elusive [10].

Rabbi Nachman praised the importance of faith in the religious life of the Jews. In his opinion, it is by faith that a person joins the Lord and in this connection lies the meaning of human existence. The priority of faith over reason in the service of God is noted [1].

Hasids believe in one God. It doesn't matter to the Lord whether you are a Jew or not. They even have a prayer for all the living on earth. God gave people the law. It is not easy to follow and consists of 613 rules. It takes at least 20 years to understand them. And sometimes - lifetime. The Hasidim do not consider themselves superior to others, they have simply chosen the more difficult path. God's law applies to all people on earth. Other Jews are satisfied with seven. Hasidism can be accepted by a person of any nationality: Ukrainian, Polish, Arab, Chinese.

Throughout the nineteenth century, the teachings of the Bratslav rabbi were actively spread among the Jewish communities of Ukraine, Poland, and with the beginning of mass Jewish emigration in the twentieth century - in the United States, Canada, Israel, France, England, Belgium, Holland, Australia, Japan, Tunisia and other countries.

In the Soviet Union, after the October coup, the fate of the Bratslav Hasids was tragic. In the 1930s, the NKVD-KGB took control of the Tzaddik burial site in Uman. Pilgrims were not allowed on the grave, the territory of the cemetery was given for individual buildings and gardens. The synagogue, built on the initiative of Rabbi Nathan Sterngarets to perpetuate the memory of Rabbi Nachman, was destroyed. During World War II, thousands of Bratslav Hasids were physically exterminated by the Nazis.

Until 1939, the Bratslav Hasidic movement was not organized. It was not until the 1970s that small groups of unusually dressed people began to appear in Kyiv (a black coat or cloak, a white shirt, a black hat or cap, and a hairstyle with "paces") [10].

The Hasidim walk in black clothes so that God can distinguish the Jews. But the form of clothing they wear is just a tradition. They wear the form of clothing that their parents once wore, and to them grandparents. But every Hasid can wear ordinary clothes. But in Ukraine, Spain, Italy, France, and many other countries, Hasids recognize each other by their clothing. Rabbi Nachman did not see the difference between the believers, although they dressed according to different patterns and were citizens of different countries.

Hasids have only been allowed to visit their holy sites since the second half of the 1980s. On the basis of the Decree of the President of Ukraine in 1994, a historical and cultural center of the Bratslav Hasids was established, and one of the largest synagogues in Europe was built. In 1998, a pantheon was built on the foundation of a residential building - the temple of Rabbi Nachman, and next to it - a hotel and a mikvah (ritual pool for recitation before prayer).

With the participation of the governmental structures of Kyiv, the Uman City Executive Committee and the regional administration, the necessary documents on the organization of the reception of visitors were agreed with the World Council of Bratslav Hasids and the Jewish religious community of Uman. The tomb of Rabbi Nachman was included in the list of monuments under state protection, and long-term leased plots of land were built for the construction of a synagogue and a hotel; the Statute of the International Charitable Foundation named after Rabbi Nachman was registered [10].

In 2005, at the request of the Jewish community, the Uman City Executive Committee gave permission for a memorial to be erected in this place, with the inscription in Ukrainian, English and Hebrew: "Here is the house where Rabbi Nachman, a spiritual preacher of Bratslav Hasids, lived in 1810" [1].

The Bratslav Hasidic community has tens of thousands of followers. Hasidism became a stronghold of orthodox Judaism, and Uman became the international capital of Bratslav Hasids. Belief in the power and majesty of Tzaddik Nachman became one of the strongest ideas of Hasidism. Among other Hasidic communities, they are distinguished by cohesion and active missionary activity. The community is headed by the World Council of Bratslav Hasids.

Numerous Hasidic groups are concentrated in New York (USA), Jerusalem, Bnei Brak and Tsarat (Israel). There is a religious center in Uman to preserve the heritage of Rabbi Nachman. The community spends a lot of money on publishing his literary heritage [10]. 
Today in many countries of the world Jews sing a song in which the words of Tzaddik Nachman are repeated many times: “The main thing is not to despair. Just don't despair! In no case do not despair! " A person should do everything in his power to rejoice and help other people to rejoice. Man must always believe in God, be sure that the Almighty is always in him and with him. This is the main idea of the philosophical teachings of Tzaddik Nachman" [12].

In September 1988, the Hasids came to Uman for the first time. Kyiv and Israel agreed to come to Uman to the tomb of the tzaddik of the first group of 200 believers. Since then, such visits have become annual. In Uman, Cherkasy region, a place of mass pilgrimage, from many countries of the world to the tomb of Tzaddik Rabbi Nachman on the Jewish New Year - Rosh Hashanah comes every year from 25 to 30 thousand and more pilgrims.

With the arrival of the Hasidim on Pushkin Street and on the adjacent streets, a passport regime is introduced and Uman residents who live here must always carry a passport.

For a city like Uman - with a population of about 80,000 - it is problematic to receive such a large number of guests, and the stay of Hasidim in the city lasts for 7-10 days. In addition to foreigners, a significant number of law enforcement officers come to the city, who also need to be resettled. There are not enough places in dormitories and hotels for everyone. Therefore, the subsidiary of Uman-Yiddish-Tour LLC partially assumes the problem of Hasidic settlement. A significant number of "tourists" stay in apartments and private homes of Uman residents. The Hasidim inform the owners of the apartments about their arrival before they cross the border. A place in a hotel these days can cost up to 3 thousand USD. All rooms are booked many months in advance. Problems also arise with renting apartments.

Regarding the registration of the Hasidic homeowners, the latter require that the following clauses be included in the agreement:

- the person renting the house undertakes to release the apartment (or house) from the presence of all family members for the entire period of renting it;

- undertakes to delete all paintings depicting women, all books and other printed publications;

- no women, including the housewife and her relatives, will come to rent it during the whole term of renting out the apartment.

Uman residents who own real estate, in the days of a mass influx of pilgrims from renting housing receive income. High salaries are paid to engineering and technical personnel and skilled construction workers. In 2016-2019 alone, more than 1 billion USD was invested in the construction of the city's hotels [13].

Staying in a small town, Uman, pilgrims from the Middle East, the EU, America, and many other countries of the world gives thousands of Uman residents the opportunity to earn some money. They provide trade and transport services to pilgrims and provide household services.

Funds come from pilgrims and their organizational structures to the city budget, its services and structures, which allows city leaders to implement certain projects.

The annual cycle of Jewish holidays opens with Rosh Hashanah, the New Year that lasts the first days of the autumn month. To celebrate Rosh Hashanah, the Hasidim need: a lamb's horn shofar, apples and honey, carrots, sliced like coins, a pomegranate, a round hall, symbolizing the unity of the Jewish people, the head of a fish to become the head in the new year, and no tail, kosher wine and candles [14].

Rosh Hashanah is the birthday of the World. According to the Torah (Old Testament), the world was created in seven days. However, on the sixth day, the Almighty created the first man, Adam. From this day begins the chronology of the Jewish calendar. The main meaning of the Jewish New Year is that every Hasid must analyze his actions and prepare for the next year.

Hasidic pilgrims celebrate Rosh Hashanah cheerfully, with songs and dances, and the people of Uman rejoice with them.

On a small area of about two and a half hectares, near the prayer house, in which the tomb of Rabbi Nachman's tzaddik (one part of which goes to the women's hall, the other to the men's hall) is built into the wall, 25 to 30 thousand pilgrims pray. The Hasidim are convinced that during the prayer on Rosh Hashanah, Uman becomes the safest place on Earth. Visiting the tomb, the Hasids feel a special holiness that prevails in this place.

Grand Rabbi Nachman commanded that when a Hasid lit a candle on his grave on Rosh Hashanah, recited the prayer of God's revelation, Tikun Aklali, and donated at least a few kopecks 
to the Udok, he himself, his children, and his grandchildren him, the grandchildren of the grandchildren will be honored with great mercy [12].

On Rosh Hashanah, it is important to apologize to each other. In the morning one should pray to the sounds of the shofar (ram's horn), because it is believed that through this instrument the sky opens and every word goes to God. It is important for Hasids to celebrate in white clothes, which symbolizes the beginning of the year from scratch. Men shave naked on this occasion, leaving only "paces" and a beard. Only men take part in the New Year celebration. And the Hasids go to Uman for the holidays in August: the unmarried wear wedding dresses to get married next year, scatter candy, dance all night. Every year 4-5 thousand women have so much fun in Uman [14].

In 2011, Rabbi Nakhman's great-granddaughter Leia Dzhergovskaya came to Uman from Uzbekistan at the invitation of the community, which remained to live here. Sarah Leia says that about 80 families live in the Hasidic quarter. The magazine-newspaper "Public" describes the life of the Hasidim as follows: "We live together, we help each other. We have our own kindergarten and school. Many work in hotels. The Rabbi Nachman Foundation helps the poor Hasids. It is replenished at the expense of millionaires - in this way the rich beg for sins. Rich Jews give, poor take and pray for their benefactors" [13].

In addition to celebrating the Jewish New Year, large groups of Hasidim come throughout the year to celebrate Passover, Shabbat, Sukkot, Purim, and small groups on other days to pray at the grave. Some believers live for weeks hoping to be healed by repeated prayers from serious illnesses and difficult life situations [10].

It is a great happiness for a Hasidic family to have 12-15 or even 20 children. According to Haim Khazin, a representative of the Hasidic community in Uman, there were cases when those who could not have children prayed at the tomb of the tzaddik - and a miracle happened. Both health and marital happiness are prayed for here.

On Shabbat, Saturday, nothing can be done to the Hasidim. Even pick up money, turn off the lights or turn on the tap. So sometimes there are problems with pilgrims renting accommodation from locals. However, locals suffer from these inconveniences in order to earn money [11].

Locals say that "Hasids are not a problem", "they are the same as other people", "everywhere there are their crazy, but most are normal". However, every year more and more Hasids want to buy housing in Uman. The plot for construction on Pushkin Street already costs one million US dollars, in remote areas - 20-50 thousand US dollars. In the Nova Uman and Lysa Hora neighborhoods, almost everything has already been bought. There are many families who have a house or an apartment here and come only to Rosh Hashanah for a few days.

Recently, many hotel complexes, restaurants, cafes, and shops have been built on Pushkin and Belinsky Streets, with "Hebrew" inscriptions and virtually no Ukrainian inscriptions. In Ukraine, there are regulations governing this procedure. But the "mini Israel" in the center of Uman ignores them. It seems that the Hasidim consider themselves the complete masters of these territories and objects.

Public organizations of the city have repeatedly appealed to local authorities, demanding streamlining the process of Hasidic stay and advertising in the city. But the authorities demonstratively ignore their appeals.

In October 2019, Uman was visited by Aide to the President of Ukraine A. Yermak, who stated that "Uman wants to be made the second Jerusalem [15].

In order to promote the development of the city as an international tourist center of Hasidic pilgrimage, the creation of modern tourist infrastructure, solving the problems of Hasidic pilgrimage provided by the Decree of the President of Ukraine "On measures to support culture, cultural heritage, creative industries and tourism” (August 2020). ) No. 329/2020 The Verkhovna Rada of Ukraine resolves [16]:

- to establish a permanent commission on Hasidic pilgrimage under the Cabinet of Ministers of Ukraine chaired by the Vice Prime Minister of Ukraine, which will include representatives of relevant ministries, state agencies and services, the head of the Cherkasy regional state administration, Uman mayor, representatives of the Israeli embassy in Ukraine, representatives of public, religious organizations of Hasids, investors, people's deputies of Ukraine and other interested persons;

- to include in the national program "Large construction", "25 magnets" construction of the international airport in the city of Uman, construction of a helicopter platform for transportation of 
seriously ill citizens, construction of the complex "Little Jerusalem" which includes construction of historical museum, park, reconstruction of synagogue, development of tourist infrastructure cities;

- to take measures to popularize and increase the tourist attractiveness of the Historical and Cultural Center at the burial place of the spiritual leader of the Bratslav Hasids Rabbi Nachman.

During the stay of the Hasidim in Uman, law enforcement agencies take all necessary measures to ensure that they do not have problems. To maintain public order, about 500-600 police officers and 20-30 Jewish police officers are involved each year, serving around the clock. These days, the city is conventionally divided into three sectors of special attention: the neighborhood with a pantheon of tzaddik and a synagogue, St. Sophia Park and the central part of the city. Patrol cars work around the clock on the routes, in Sofia Park - bicycle patrols, groups of explosives technicians. During all the years of the Hasidic pilgrims' stay in the city, no serious incidents occurred, although some conflicts took place.

The main attention of the State Emergency Service of Ukraine is focused on the organization of safety of pilgrims of the city. All events are carried out in close cooperation with the National Police, local authorities, with the organizers of the event in the city of Uman, as well as representatives of the Israeli police.

Fire and technical safety measures are provided by 110-120 personnel and from 25 to 30 units of equipment of the consolidated detachment of the State Emergency Service.

The Hasidim have a ritual that they perform near water. Therefore, measures are being taken to avoid tragedies on the water: groups of rescuers and divers are constantly on duty near Uman ponds.

During their stay in Uman, some Hasids behave as they please, discrediting their nation and religion, leaving a lot of garbage on the city streets and in the arboretum "Sofiyivka".

Having celebrated the New Jewish Year, paying homage to the glorious tzaddik, being healed, being photographed in the Assembly Square and the Island of Love, most of the Hasidim leave the hospitable Uman for a few days.

For thirty-eight and a half years of his life, Tzaddik Nachman sowed the eternal seeds of holiness that have borne fruit today: great love for every Jew, brotherly support, joy and comfort to the people. Even in seemingly hopeless situations, Rabbi Nachman gives simple and effective advice to a person who seems to have no hope.

After the death of Tzaddik Nachman, his influence on the faithful did not diminish. In addition to books that radiate the holiness that enters every home and heart, he left the Jews a place where they could meet him.

Tzaddik Nachman preached his teachings not only to his Hasidic followers. His clear and insightful words are addressed to the entire Jewish people, of all generations.

\section{Discussion}

At present, the Bratslav Hasids, as part of the religious orthodox movement in Judaism, have not been identified as a special object of study. As a rule, scientific sources consider general historical aspects of the origin and functioning of Hasidism as a movement in Judaism, which is widespread among the Jewish population of Volhynia, Galicia and Podillya, which aimed to achieve the independence of the Jewish religion [2].

The founder of Hasidism in Ukraine was a rabbi and healer Israel Baal Shem Tov (nicknamed Besht) from Medzhibozh [3].

Without rejecting traditional doctrine, the Hasidim emphasize the need for an emotional attitude towards religion and spiritual renewal. According to the doctrine, pious Jews should be distinguished not by strict observance of the law and not by asceticism, but by a cheerful heart of reverence and humility [4].

Among the Hasidim, the Tzaddik heirs, the religious leaders of certain groups of Hasidim, who are credited with miraculous abilities, enjoy great authority. Hasidism preaches the principle that the tzaddik is the mediator between God and the believer.

Nowadays, due to the growing interest in the teachings of Tzaddik Nachman and about 30,000 pilgrims from more than 20 countries come to Uman every year, the phenomenon of this phenomenon needs further research.

The study revealed the role of one of the most influential movements of Bratslav Hasidim, founded and led by Rabbi Nachman of Bratslav, the main religious teachings of his teachings, the reasons for its rapid spread among the communities of Ukraine and many countries. 
A significant amount of literature has been published on the problem under study, which reflects the historical aspects of the emergence of the Hasidic movement and, in particular, the teachings of the Bratslav Hasids, the life and teachings of Rabbi Nachman. But the vast majority of them appeared before the mid-1980s and were ideologically influenced by the past years.

The results of the study can be used by historians, political scientists and other experts to further study the Bratslav Hasids as a religious orthodox movement in Judaism. Materials and conclusions of the study can be used to create works that summarize the history of political, social, national and cultural development of Ukraine, in the preparation of scientific papers, textbooks and manuals, the creation of special courses on Hasidism, Bratslav Hasids.

Further study of the historical process of origin and functioning of the religious orthodox movement in Judaism will be aimed at defining and characterizing the teachings of Tzaddik Nachman, his religious teachings and solving the problems of pilgrims coming to Uman.

\section{Conclusions}

1. The historical reasons for the origin and functioning of the Bratslav Hasids as a component of the Orthodox movement in Judaism and its spread among the Jewish population of Volhynia, Galicia and Podillya as a way to achieve the formation of the Jewish religion are revealed.

2. The role of one of the most influential movements of Bratslav Hasids, the founder and leader of which was Rabbi Nachman from Bratslav, has been studied.

3. The way in which the Hasidic believers of Bratslav took to obtain permission to celebrate the Jewish New Year - Rosh Hashanah and to resolve other issues at the grave of their teacher and mentor is highlighted.

4. The problems of pilgrims' arrival in Uman and religious instructions, conditions that contributed to the transformation of the city of Uman into the world capital of Bratslav Hasids were identified and substantiated.

\section{References}

[1] Kryvosheia, I., Furkalo, V. (2007). Khasydy v Umani: istoriia i suchasnist. Uman: RVTs «Sofiia», 18.

[2] Filosofskii entsiklopedicheskii slovar (2000). Moscow: INFRA-M, 576.

[3] Dubnov, S. M. (1888). Vvedenie v istoriiu khasidizma. Voskhod. Vol. 1. Saint Petersburg, 83-110.

[4] Dubnov, S. M. (1890). Istoriia khasidskogo raskola. Voskhod. Vol. 2. Saint Petersburg, 88.

[5] Dubnov, S. M. (1889). Vozniknovenie khasidizma. Voskhod. Vol. 9. Saint Petersburg, 3.

[6] Dubnov, S. M. (1888). Vozniknovenie khasidizma. Zhizn i deiatelnost Izrailia Beshta. Voskhod. Vol. 10. Saint Petersburg, 27.

[7] Turov, I. (2003). Rannii khasidizm: Istoriia. Verouchenie. Kontakt so slavianskim okruzheniem. Kyiv, 118.

[8] Velykyi tlumachnyi slovnyk. Suchasna ukrainska mova vid A do Ya (2008). Donetsk: TOV VKF «BAO», 645.

[9] Moskalenko, L. (2007). Tsadykizm yak element khasydskoho virovchennia. Universytet, 4, 52-57.

[10] Uchenie rabi Nakhmana iz Bratslava (1991). Ierusalim: Aman, 293.

[11] Furkalo, V. S., Furkalo, V. I. (2012). Kontseptualni formy khasydyzmu. Uman: PP Zhovtyi O. O., 165.

[12] Mykolaichuk, M. N. (2008). Storinky istorii ta kraieznavstva pro Uman. Uman: VPTs «Vizavi», 364-365.

[13] Entsiklopediia publichnoi i lichnoi zhizni (2019). Publika, 39, 18.

[14] Shelupets, I. (2019). Nakhman tvorit dlia nikh chudo. Ekspres, 38, 13.

[15] Pogliad chasu (2019). 46, 2.

[16] Pro zvernennia Verkhovnoi Rady Ukrainy do Kabinetu Ministriv Ukrainy, ministerstv, derzhavnykh sluzhb, ahentstv, mistsevykh orhaniv vlady shchodo zdiisnennia zakhodiv, spriamovanykh na rozvytok mista Uman yak mizhnarodnoho tsentru palomnytstva khasydiv (2020). Proekt postanovy. 20.11.2020. Available at: http://w1.c1.rada.gov.ua/pls/zweb2/webproc4_1?pf3511=70524 